\title{
An Ayurvedic Approach in Management of Polycystic Ovarian Syndrome
}

\author{
Review Article
}

\section{Saroj Kumari ${ }^{*}$, Sarvesh Kumar Singh², Kshipra Rajoria ${ }^{3}$, Avadhesh Kumar ${ }^{4}$}

\author{
1. PG Scholar, 2. Assistant Professor, 3. Lecturer, 4. PG Scholar
}

PG Department of Panchakarma, National Institute of Ayurveda, Jaipur.

\begin{abstract}
Polycystic ovarian syndrome (PCOS) is a probably fastest growing endocrinological disorder in females of reproductive age. In PCOS, follicular growth is influenced by hormonal imbalance during the ovarian cycle, leads to affected follicles remain in the ovary. The prevalence of PCOS is estimated $6-10 \%$ globally and $3.7 \%-22.5 \%$ in Indian female population, which is relatively high. It is characterised by hyperandrogenism, anovulation and polycystic ovaries which clinically manifests in the terms of amenorrhea or oligomenorrhea, hirsutism, acne, infertility etc. In present scenario, incidence of this disease increasing exponentially due to sedentary lifestyle and faulty dietary habits. This particular disease is not described word to word in Ayurveda. Associated features of PCOS are closely resembling with Bandhya Yonivyapada, Artavavahasrotasa-Vidhha Lakshana, Nastartava and Ksheenaartava described by Acharya Sushruta and Pushpghani Jatharini and Vikuta Jatharini mentioned by Acharya Kashyap. Maximum congruence of PCOD can be established with Bandhya Yonivyapada. The purpose of this study is to understand Nastartava which is the cardinal feature of Bandhya. Word Artava has been used exclusively in Samhita in context of menstrual blood, ovum and ovarian hormones. Therefore Amenorrhea, anovulation, hormonal dysfunction is considered exposed manifestations of Nastartava. Possible line of treatment is stipulated with Nidanaparivarjan, herbal drugs and Panchakarma procedures.
\end{abstract}

Key Words: Ayurveda, Artava, Nastartava, PCOS, Herbal drugs, Panchakarma.

\section{Introduction}

In today's era polycystic ovarian syndrome (PCOS) is an emerging endocrinological disorder leading to reproductive as well as metabolic dysfunctions affecting $6-14 \%$ of child bearing age of females (1). Polycystic ovarian syndrome (PCOS) also known as Stein Leventhal Syndrome, functional ovarian hyperandrogenism, ovarian hyperthecosis and sclerocystic ovary. PCOS characterised by classical triad of symptoms by hyperandrogenism, anovulation and polycystic ovarian morphology (2). It also has associated comorbidities which include irregular menses, infertility, insulin resistance leads to Type 2 Diabetes and obesity, hirustism, alopecia, acne, anxiety, depression and sleep apnea, cancer and coronary heart disease (3). The prevalence of PCOS differs according to different diagnostic as well as geographic regions, worldwide it is estimated to be $6-10 \%$ or even $15 \%$ when the diagnosis is based on Rotterdam criteria (4). It affects female of age ranging from 18-45 years age (5). In India prevalence is $3.7 \%$ to $22.5 \%$ reported by the Indian Fertility Society with 9.13 to $36 \%$ prevalence in adolescents only (6). It also affects $28 \%$ of unselected obese and $5 \%$ of lean females (7). Due to wide range of

\section{* Corresponding Author:}

\section{Saroj Kumari}

PG Scholar,

PG Department of Panchakarma,

National Institute of Ayurveda,

Jaipur India.

Email Id: drsarojkumari99@gmail.com sign and symptoms and different clinical presentation it is underdiagnosed or not diagnosed properly. Due to variability of symptoms patients may seek help from a gynaecologist, dermatologist, endocrinologist or general practitioner and lack of well- defined diagnostic criteria mimics any disease and create illusion for the identification of this common disorder to the clinician. Furthermore, it is more annoying for female because with time distressing aspect of disease changes like from hirsutism, acne as a teenager to infertility as an adult. PCOS is a major cause of infertility in females. In modern modality treatment is symptomatic which includes oral contraceptives, periodic progesterone withdrawal, and metformin, anti-androgen and clomiphene citrate. But they have their own complications like long term use of Mt associated with fatal and nonfatal lactic acidosis, oral contraceptives associated with weight gain, cardiovascular and thromboembolic events and AA associated with hepatic toxicity which could be fatal (8). So, its need of time for safe and cost-effective treatment protocol for this multifactorial disease.

\section{PCOS in Classics}

According to Acharya all disease should be examined by Nidanpanchak (five-fold examination) (9). But none of gynaecological disorder described in this manner, there is only explanation of Nidana (Causative factor) and Chikitsa (Treatment). In the same way regarding PCOS, all the associated commodities should be assumed as different pathological conditions of Dosha, Dushya, and Roga Adhishthana. Variation in these constituents results in variation of onset, sign and 
symptoms of disease. In Ayurveda, most of the gynaecological disorders explained under the roof of Yonivyapada although some disorders described separately. PCOS is not described as a particular disease, its features closely relate with Bandhaytava Yonivyapada, Nastartava and Ksheenaartava told by Acharya Sushruta and Pushpghani Jatharini and Vikuta Jatharini told by Kashyap. Its symptoms also similarize with Artavavahasrotasa Vidhha Lakshana told by Acharya Sushruta. Acharya Sushruta elaborated Bandhaytava Yonivyapada as a condition in which Nastartava is the main feature (10). He also described Nastartava separately where they narrated eight disorders of Artava. In this condition Artava is not completely destroyed but not apparent due to obstruction in channels by encircled Vata and Kapha which results in amenorrhoea (11). In Samhita Artava word extensively used in context of menstrual blood, ovum and ovarian hormones.

If we narrate Artava as menstrual blood, in Nastartava passage of Artava carrying channels is obstructed due to obstruction of Artavavahasrotasa by Vata and Kapha Dosha. So Artava is not evident monthly as in regular menstrual cycle bleeding which leads to amenorrhoea. In Vikuta Jatharini also female has irregular menses in terms of time, quantity and colour which results in lethargy and weakness without any cause (12).

If we narrate Artava as ovum then we can consider Nastartava as anovulatory cycles which causes infertility. Ovum is a microscopic structure and its presence can be only assumed by its role in conception (13). Keeping this in view, we can consider Pushpghani Jatharini as female whose menstrual flow is regular but cycle is without ovulation. It results in corpulent and hairy cheeks which are associated comorbidities with PCOS (14). This condition is seen in PCOS as 30\% of women with PCOS have normal menses (15).

If Artava is considered as ovarian hormones, the basic pathology of PCOS can be understood in context of Avarana by Dosha. This Avarana disrupts homeostasis of HPO axis causing hormonal imbalance leading to PCOS.

\section{Nidana (causative factors) (16)}

PCOS is functional disorder of unclear aetiology and as such, is a diagnosis of exclusion with other androgen and ovulatory disorder of clearly defined aetiologies. We can correlate PCOS with Bandhya Yonivyapada and Nastartava. As in our classics no specific aetiology is described, so general causative factors for Yonivyapada can be considered as etiological factors:

\section{Mithyachara}

It includes Mithyaahara (faulty dietary habits) and Mithyavihara (faulty life style) both. In PCOS we can include pizza, burger, bread, cold drinks, spicy, oily, junk food consumption under faulty dietary habits. It is found that reproductive age women which are undergoing rapid nutritional transitions due to westernized diets and lifestyles prevalence of PCOS estimated to be $5 \%-10 \%$ in general population (17). A survey report conducted on 100 subjects concluded aggravating factors which includes Aharaja Nidana like
Aashana, Vishamashana, Ati Madhura Ahara Sevana, Ati Katu and Vidahi Ahara Sevana and Viharaja Nidana includes Avayama, Divaswapana, Ratijagrana, Mutravegdharana and Atichinta, so they can be considered as Mithyachara in PCOS (18).

\section{Pradushtartava}

The word Artava should be used for ovarian hormones. As menstrual flow is due to cyclic endometrial shedding under the regulation of various hormones of HPO axis. In PCOS ovarian compartment is the biggest contributor of androgens. Dysregulation of CYP 17, the androgen forming enzyme in both adrenals and ovaries may be the main pathologic mechanism underlying Hyperandrogenism in PCOS.

\section{Bijadosha}

Chromosomal and genetic abnormality comes under Bijadosha. During intrauterine life excessive exposure to androgens have a permanent effect on gene expression resulting in PCOS and later to insulin resistance (19). PCOS is genetically determined ovarian disorder and the heterogeneity explained on the basis of interaction of the disorder with other genes and with environment. Its genetic origins are likely polygenic and/or multifactorial although low birth weight and foetal exposure to androgens leads to development of PCOS phenotype (20). A high prevalence of PCOS or its features among first degree relatives is suggestive of genetic influences (21). A study shown that gene-based association of polymorphisms in genes involved in steroidogenesis as well as androgen levels and action which are presumed to govern PCOS susceptibility and phenotypic heterogeneity of the disorder (22). Genes like CAPN10, Cytochrome family p450, Insulin gene, AR, FTO, and FSHR have strong genetic association (23).

\section{Daiva}

Unknown or idiopathic causes comes under Daiva. Each cause has its own causative process, potential and mode of action.

\section{Clinical Features}

Approximately $85 \%-90 \%$ of women with oligomenorrhea have PCOS while $30 \%-40 \%$ of women with amenorrhea will have PCOS (24).

Hirsutism is found in $70 \%$ of women with PCOS which is common presentation of hyperandrogenism (25).

Acne approximately found in 15\%-30\% adult women with PCOS can also be marker of hyperandrogenism (26).

Infertility affects $40 \%$ of women with PCOS. Approximately $90 \%-95 \%$ of anovulatory women presenting infertility have PCOS (27). Moreover, spontaneous abortion occurs frequently in PCOS with incidence ranging from $42 \%-73 \%$ (28).

Approximately $20 \%$ of females experienced sleep apnea. Depression and anxiety are common complains (29).

There is an insulin resistance which results in obesity and Type 2 diabetes. 


\section{Diagnostic Criteria}

National Institutes of Health Criteria $(\mathrm{NIH})$, in 1990 defined and comprises only presence of clinical and/ or biochemical hyperandrogenism and oligo/ amenorrhea anovulation. Rather than clinical trial it was based on consensus (30). In 2003, the Rotterdam Criteria added polycystic ovarian morphology in ultrasound as a new creation in the two previous criteria of NIH. The European Society of Human Reproduction and Embryology (ESHRE)/ American Society for Human Reproductive Medicine (ASRM) elaborated diagnosis of PCOS mandates two out of three anovulation/ oligo-ovulation, hyperandrogenism (Clinical or Biochemical) and appearance of polycystic ovaries in Ultrasound (31) (in ultrasound criteria for PCOS mandates the presence of 12 or more follicles measuring 2-9 $\mathrm{mm}$ in diameter and / or increased volume $>10 \mathrm{cc}$ in either of ovary). In 2006, the Androgen Excess Society (AES) finally defined PCOS as hyperandrogenism with ovarian dysfunction or polycystic ovaries. AES considered Androgen excess as a main cause for pathology of PCOS and established that hyperandrogenaemia should be present accompanied by oligomenorrhoea or polycystic ovarian morphology or both of them (32).NIH sponsored an evidence-based methodology workshop on PCOS in 2012, expert panel estimated each criteria has its own strength and limitations; however, considering multiple criteria creates dilemma in understanding PCOS. If PCOS is suspected, complete medical history, physical examinations, haematological tests, and pelvic ultrasound should be advised. The Medical history and physical examination give the information about menstrual cycle's irregularities, unexplained weight gain, male pattern hair growth, skin changes, unexplained weight gain and raised blood pressure. The haematological tests are performed to assess the hormones, lipids and glucose level and ultrasound is performed for screening ovarian cysts. During assessment other major and potential cause related with endocrine, reproductive and metabolic dysfunctions should be excluded. Before diagnosing PCOS, adrenal hyperplasia, Cushing's syndrome, and hyperprolactinemia, non- classical congenital adrenal hyperplasia, androgen- secreting tumours and drugsinduced androgen excess should be ruled out (33).

\section{Management}

The management of PCOS should aim to normalize the menstrual cycle, achieve ovulation, and eliminate hirsutism, acne, to reduce weight as well as manage hyperglycaemia and hyperlipidaemia to lower the risk of cardiovascular disease. Acharya Dalhana mentioned that due to regular menses, as impurities are excreted from woman body constantly, so there are less chances of her to suffer from Prameha (34). As one of the cause of PCOS is hyperinsulinemia, so we can use Pramehghna drugs. Weight loss leads to increase circulating androgen and glucose levels but also beneficial in ovulation and thus combating the infertility rate in obese females with PCOS. The line of treatment for PCOS patient depends only on the basis of symptoms. So, management for PCOS should be planned with following considerations-

\section{Nidana Parivarjana}

Nidana Parivarjana (avoid the disease causing factors) for which women should follow the principles of Swasthaya Rakshana like Dincharya (daily regimen), Ritucharya (seasonal regimen), Sadvritta, Achara Rasayana, Hitahara ,Samyaka Nidra (proper sleep of 6-8 hours in night) and Vyayama (physical activity) for prevention of disease. Results of study reported that there are subtle variations in diets, monounsaturated enriched diet results in greater weight loss; low glycaemic diets decreased insulin resistance, fibrinogen, total and high lipoprotein density, improved menstrual irregularities (35).

\section{Exercise}

Many studies have reported that regular exercise improves menstrual irregularity and insulin resistance. In PCOS, physical activity and exercise for 30-45 minutes showed improvement in body mass index, waist circumference and metabolic parameters such as insulin resistance, total cholesterol and lipid profile. Thereby reducing the metabolic syndrome and other risk factors contributing to PCOS (36).

\section{Drugs used for PCOS \\ Yashtimadhu- \\ Glycyrrhiza glabra L. (Family-Fabaceace)}

Effect of liquorice was investigated on androgen metabolism and it is found that it can reduce serum testosterone might be due to block of 17Hydroxysteroid dehydrogenase and 17-20 lipase. Therefore, liquorice is beneficial for hirustism and PCOS (37).

\section{Meshshringi- \\ Gymnena sylvestre R.BR. (Family-Asclepiadaceae)}

Studies done Gymnena supplementation reported that it reduces the absorption of glucose in intestines, stimulates beta cell pancreatic growth and insulin release from beta cells (38).

\section{Shatavari- \\ Asparagus racemosus Willd. (Family-Liliaceae)}

Many researches prove that it is beneficial in infertility as it stimulates folliculogenesis, ovulation, prepares the uterus for conception and prevents miscarriages. Its alcohol extract significantly enhances insulin release (39).

\section{Methika- \\ Trigonella foenum graceum L. (Family- Fabaceace)}

Studies on seed extract of Trigonella foenum shown significant reduction in ovary volume and size of cyst. It also showed increase in LH and FSH (40).

\section{Kumari-}

\section{Aloe vera L. (Family- Liliaceae) -}

Experimental studies shown that Aloe Vera decrease the levels of testosterone and insulin through improving the levels of progesterone and estradiol; decreasing the transcription levels of steroid receptors; increasing aromatase expression (41). Aromatase is member of family p450 cytochrome who converts testosterone into estradiol and androstenedione into 
estrogen. Many preclinical studies reported its role in reversion of estrus cyclicity to normal by regulating hyperglycaemia and modulating steroidogenesis (42).

\section{Jatamamshi-}

Nardostachys jatamansi DC. (Family- Valerianaceae)-

It is reported to be beneficial in management in PCOS by its antiandrogenic effect (43).

\section{Lodhra-}

\section{Symplocos racemosa Roxb. (Family-Symplocaceae)-}

Its bark is prescribed in menorrhagia and other female reproductive dysfunctions. Many experimental studies proven that it significantly decreases the elevated levels of testosterone and restored the levels of estrogen, progesterone and cholesterol levels. It maintained the normal weight and histology of ovarian tissue and these effects were found to be comparable with clomiphene citrate (44).

\section{Panchakarma Treatment}

Acharya Sushruta told that in Artava Kshaya Samshodhana should be done followed by use of Aagneya Dravya (45). Dalhana commentates that for purification only Vamana Karma should be used, not Virechana Karma. As Virechana Karma reduces Pitta which results in Artava Kshaya. Vamana Karma expels Saumaya (Kapha) substance results in relative increase of Aagneya constituent of body, consequently increases Artava. Acharya Chakrapani states that use of both Vamana Karma (emesis) and Virechana Karma (purgation) clears upward and downward channels respectively. So, both procedures should be done.

\section{Vamana Karma}

Vamana helps to increase metabolism of body therefore reduce weight and specifically act on liver metabolism which is the main site of hormone formation. There is also direct relation between estrogen and obesity. Weight loss can therefore not only improve the circulation of androgen and glucose levels but also help ovulation and thus enhances pregnancy rate in obese women with PCOS (46).

\section{Basti}

As per Kashyap, Anuvasana Basti is the choice of treatment in oligomenorrhoea, amenorrhoea (47). As per contemporary science also any drug given via rectal route absorbs through mucosal layer of rectum and enters into systemic circulation. Entering Gastro Intestinal Tract (GIT), Basti stimulates the Enteric Nervous System (ENS) and generates the central nervous system (CNS) stimulating signals as the ENS resembles CNS. These signals stimulate endogenous opioids present in GIT, mostly $\beta$-endorphin, which exerts hormone-releasing inhibition of gonadotropin. Basti may stimulate the parasympathetic nerve supply which in turns helps for development of follicles and release of ovum from ovary (48).

\section{Uttara Basti}

It is highly beneficial in gynaecological disorders as it clears the Artavavahasrotasa and pacifies vitiated Apana Vayu and promotes follicular maturity.
Nasya

It may stimulate olfactory nerves and limbic system, which in turn stimulates hypothalamus leading to stimulation of Gonadotropin Releasing Hormone (GnRH) neurons, regularizing GnRH pulsatile secretion, leading to regular and normal menstrual cycle.

\section{Udavartana}

It is stated to decrease the lipids (49).

\section{Yoga-Asana}

Regular practice of Suryanamaskara, Sarvangasana, Paschimottanasana, Ardhamatsayendrasana, Matsyasana should be recommended. A clinical study was conducted on 90 participants divided randomly in two groups. One group performed conventional exercise while other group performs Suryanamaskara, Asanas, and Pranayama, relaxation techniques, meditation and lectures on lifestyle and stress management by yogic counselling. Yoga was found to be more effective than conventional exercise in terms of improving lipid, glucose including insulin resistance values in adolescent girls with PCOS (50).

\section{Pranayama-Nadishodhana Pranayama, Kapalbhati and Bhramri}

Pranayama should also be practiced as they are beneficial in PCOS. Kapalabhati - it is known to be beneficial in brain-pancreas endocrine pathway and therefore pacifies the primarily hyperinsulinism and dyslipidaemia. It also improves the blood supply to muscles and increase insulin receptor expression on the muscles. It also reduces waist- to- hip on long ratio term practice (51).

\section{Conclusion}

PCOS is a major health issue before clinicians and public, because it adversely affects female's health and have significant negative impact on quality of life. While choosing modern conventional treatment accounts for side effects and high cost of fertility drugs which increases economic burden on society. PCOS not explained vis-a-vis in Samhita but Acharya have made their point regarding treatment. Unnamed disease should be understood by their Dosha and Dushya thus treatment should be planned accordingly. Out of all Yonivyapada, Bandhya Yonivyapada shows maximum similarity with PCOS. Expanded meanings of Artava i.e. menstrual blood, ovum and hormones help to amplify PCOS symptomatology in Ayurveda context and plan its line of treatment. Therefore, the present review discusses the anticipation of disease by prevention of causative factors, drugs from plant sources, Panchakarma treatment and Yoga which are significantly effective, safer and will have low cost for proper management of PCOS and associated comorbidities.

\section{References}

1. Human Reproduction Update, Volume 19, Issue 3, May/June 2013, 268-288p.

2. Rotterdam ESHRE/ASRM- Sponsored PCOS Consensus Workshop Revised 2003 
3. consensus on diagnostic criteria and long- term health risks related to polycystic ovary syndrome (PCOS). Hum Reprod. 2004;19: 41-47

1. Erin K. Barthelmes, Rajesh K. Naz. Polycystic ovary syndrome: current status and future perspective. Front Biosci (Elite Ed). 2014; 6: 104119.

2. Nehra J, Kaushal J, Singhal SR and Ghalaut VS: A comparative study of myo inositol versus metformin on biochemical profile in polycystic ovarian syndrome in women. Int J Pharm Sci Res 2017;8(4): 1664-70.

3. Journal of Pediatric and Adolescent Gynecology Volume 24, Issue 4, August 2011, 223-227p.

4. Malik S, Jain K, Talwar P, Parsad S, Dhorepati B. Management of Polycystic Ovary Syndrome in India. Fertil sci Res 2014;1:23-43

5. Teede et al., Polycystic ovary syndrome: a complex condition with psychological, reproductive and metabolic manifestations that impacts on health across the lifespan BMC Medicine 2010,8:41

6. Juan Pablo Domecq, Gabriela Prutsky, Rebecca J. Mullan, Vishnu Sundaresh, Amy T.

7. Wang, Patricia j. Ervin, Corrine Welt, David Ehrmann, Victor M. Montori, Mohammad Hassan Murad, Adverse Effects of the Common Treatments for Polycystic Ovary Syndrome: A Systemic Review and Meta- Analysis, The Journal of Clinical Endocrinology \& Metabolism, volume 98, issue 12, 1 December 2013,4646-4654p.

8. Kashinath Shastri, Charka Samhita of Acharya Charka, Nidana sthana, Chapter 1/6, Varanasi: Chaukhamba Bharti Academy, Reprint edition, 2013, 601p.

9. Ambikadutt Shastri, Sushruta Samhita of Acharya Sushruta with Ayurveda-Tattva-Sandipika Hindi Commentary, Utara sthana, Chapter 38/10, Vol.2, Varanasi: Chaukhamba Sanskrit Sansthan, Reprint edition, 2014, 203p.

10. Ambikadutt Shastri, Sushruta Samhita of Acharya Sushruta with Ayurveda-Tattva-Sandipika Hindi Commentary, Sharir sthana, Chapter 2/23, Vol. I., Varanasi: Chaukhamba Sanskrit Sansthan, Reprint edition, 2014, 16p.

11. Shri Satyapala Bhishagagacharaya, Kashyapa Samhita of Acharaya Kashyapa, , revised by Vatsya, Sanskrit Introduction by Nepal Raja Guru, Pandit Hemraj Sharma, Kalpa sthana, Chapter Revatikalpadhaya-3, Varanasi: Chaukhamba Sanskrit Sansthan, Reprint: 2018, 290p.

12. Prof. P.V. Tiwari, Ayurvediya Prasutitantra evam Striroga (Part2), 2nd edition,Varansi: Chaukhamba Orieantaliya publication, 2000, Chp.1, 56p.

13. Shri Satyapala Bhishagagacharaya, Kashyapa Samhita of Acharaya Kashyapa, , revised by Vatsya, Sanskrit Introduction by Nepal Raja Guru, Pandit Hemraj Sharma, Kalpa sthana, Chapter Revatikalpadhaya-3, Varanasi: Chaukhamba Sanskrit Sansthan, Reprint: 2018, 290p.

14. Balen A, Conway G, Kaltsas G. Polycystic ovary syndrome: the spectrum of the disorder in 1741 patients. Hum Reprod. 1995; 10:2107-2111.

15. Kashinath Shastri, Charka Samhita of Acharya Charka, Chikitsa sthana, Chapter30/8, Varanasi:
Chaukhamba Bharti Academy, Reprint edition, 2013, 841p.

16. Allahbadia GN, Merchant R (2008) Polycystic Ovary Syndrome in the Indian subcontinent. Seminars in Reproductive Medicine 26(1): 22-34.

17. Hedge VM, Asokan V, Chetan M. A survey study to evaluate the causative Factors of PCOS and its Ayurvedic interpretation. Int $\mathrm{J}$ Health Sci. Res. 2019; 9(7): 190-194

18. Gerard C. The polycystic ovary syndrome: a position statement from the European society of endocrinology. Eur J Endocrinol 2014; 171: P1P29.

19. Crosignani PG, Nicolosi AE. Polycystic ovarian disease: heritability and heterogeneity. Hum Reprod Update. 2001; 7(1):3-7.

20. Amato P, Simpson JL. The genetics of polycystic ovary syndrome. Best Pract Res Clin Obstet Gynaecol. 2004; 18(5):707-718.

21. Dadachanji R, Shaikh N, Mukherjee S. Genetic Variants Associated with Hyperandrogenemia in PCOS Pathophysiology. Genet Res Int. 2018 Feb 18; 2018:7624932.

22. Nida Ajmal, Sanam Zeib Khan, Rozeena Shaikh. Polycystic ovary syndrome (PCOS) and genetic predisposition: A review article Eur J Obstet Gynaecol Reprod Biol X. 2019Jul; 3:100060. Published online 2019 June 8.

23. Hart R. Definitions, prevalence and symptoms of polycystic ovaries and the polycystic ovary syndrome. In: Allahbadia GN, Agrawal R, editors. Polycystic Ovary Syndrome. Kent, UK: Anshan, Ltd; 2007.15-26p. [Google Scholar]

24. Fauser B, Tarlatzis B, Rebar R, et al. Consensus on women's health aspects of polycystic ovary syndrome (PCOS): the Amsterdam ESHRE/ASRMSponsored 3rd PCOS Consensus Workshop Group. Fertil Steril. 2012; 97(1):28-38. e25. [PubMed] [Google Scholar]

25. Azziz R, Sanchez L, Knochenhauer ES, et al. Androgen excess in women: experience with over 1000 consecutive patients. J Clin Endocrinol Metab. 2004; 89(2):453- 462. [PubMed] [Google Scholar]

26. Teede H, Deeks A, Moran L. Polycystic ovary syndrome: a complex condition with psychological, reproductive and metabolic manifestations that impacts on health across the lifespan. BMC Med. 2010; 8:41. [PMC free article] [PubMed] [Google Scholar]

27. Glueck C, Phillips H, Cameron D, Sieve-Smith L, Wang P. Continuing metformin throughout pregnancy in women with polycystic ovary syndrome appears to safely reduce first-trimester spontaneous abortion: a pilot study. Fertil Steril. 2001; 75(1):46-52. [PubMed] [Google Scholar]

28. N. Helvaci, E. Karabulut. Polycystic ovary syndrome and the risk of obstructive sleep apnea: a meta-analysis and review of the literature Endocr Connect, 6 (437) (2017), 437445p.

29. Zawadski JK, Dunaif A. Diagnostic criteria for polycystic ovary syndrome. In: Givens JHF, Merriman G, editors. The Polycystic Ovary Syndrome. Cambridge, MA: Blackwell Scientific; 1992:377-384. 
30. Rotterdam ESHRE/ASRM-Sponsored PCOS Consensus Workshop Group. Revised 2003 consensus on diagnostic criteria and long-term health risks related to polycystic ovary syndrome. Fertil Steril. 2004; 81:19-25.

31. Ricardo Azziz, Diagnosis of Polycystic Ovarian Syndrome: The Rotterdam Criteria Are Premature, The Journal of Clinical Endocrinology \& Metabolism, Volume 91, Issue 3, 1 march 2006, 781- 785p.

32. Majid Bani Mohammad, Abbas Majdi Seghinsara. Polycystic Ovary Syndrome (PCOS), Diagnostic Criteria, and AMH. Asian Pac J Cancer Prev. 2017; 18(1):17-21.

33. Sharma P V, Sushruta Samhita of Acharya Sushruta, with Nibandhasangraha Commentary, Nidana sthana, Chapter 6/3, Varanasi: Chaukhamba Orientalia, Reprint edition, 2014, 289p.

34. Moran LJ, et al. Dietary composition in the treatment of polycystic ovary syndrome:

35. a systematic review to inform evidence-based guidelines J Acad Nutr Diet.2013 Apr;113(4):520-45

36. Shetty D, Chandrasekaran B, Singh AW, Oliverraj J. Exercise in polycystic ovarian syndrome: An evidence - based review. Saudi J Sports Med 2017; 17:123-8

37. Decio A et al. Liquorice reduces serum testosterone in healthy women, Steroids, 2004; 69(11-12): 763-66.

38. Shukla Sonal and Shukla Sanjay. A review on Karmukta of Ayurvedic drugs used for Polycystic Ovary Syndrome (PCOS). Int. J. Res. Ayurveda Pharm. 2017;8(6):55-57

39. Impact of stress on female reproductive health disorders: Possible beneficial effects of shatavari (Asparagus racemosus). Biomedicine \& Pharmacotherapy Volume 103, July 2018, 46-49p.

40. Bashtian MH, Emami SA, Mousavifar A, Poor AH. Evaluation of fenugreek (Trigonella foenum graceum L.) effects seed extract on insulin resistance in women with PCOS. International Journal of Pharmaceutical Research 2013;12(2): 475-481

41. M. Radha, N. Laxmipriya, Efficacy of non polar extract (NPE) of aloe barbadensis mill. In polycystic ovarian syndrome (PCOS) rodent model- an “in vivo" study, Int. J. Pharm. Sci. Res. 7 (2016) 4933.

42. Miller LG, Murray WJ. Herbal medicinals: a clinician's guide. Routledge, $2^{\text {nd }}$ ed., 1998:326-342

43. Palarhil S, Mavilavalappil, Toine B, Krishnan S. Antiandrogenic activity of Nardostachys jatamansi DC and Tribulus terestris Linn and their beneficial effects on Polycystic Ovary syndrome- induced rat model. Metabolic syndrome and related disorders 2015; 6(1): 248-254.

44. Jadhav, Mamata \& Menon, Sasikumar \& Shailajan, Sunita. (2015). Anti-androgenic effect of Symplocos racemosa Roxb. against letrozole induced polycystic ovary using rat model. Journal of Coastal Life Medicine. 1.10.12980/ JCLM.1.2013C79

45. Ambikadutt Shastri, Sushruta Samhita of Acharya Sushruta with Ayurveda-Tattva-Sandipika Hindi Commentary, Sutra sthana, Chapter 24/51, Vol. I., Varanasi: Chaukhamba Sanskrit Sansthan, Reprint edition, 2014, 77p.

46. Bhingardive KB, Sarvade DD, Bhatted S. Clinical efficacy of Vamana Karma with Ikshwaaku Beeja Yoga followed by Shatapushpadi Ghanavati in the management of Artava Kshaya w. s. r to polycystic ovarian syndrome. Ayu. 2017; 38(34):127-132.

47. Shri Satyapala Bhishagagacharaya, Kashyapa Samhita of Acharaya Kashyapa, , revised by Vatsya, Sanskrit Introduction by Nepal Raja Guru, Pandit Hemraj Sharma, Siddhisthana, Chapter 7/11 Varanasi: Chaukhamba Sanskrit Sansthan, Reprint: 2018, 250p.

48. Rajan R., Postgraduate Reproductive Endocrinology, Jaypee Brothers, 4th ed., (2004)201-5.

49. Ambikadutt Shastri, Sushruta Samhita of Acharya Sushruta with Ayurveda-Tattva-Sandipika Hindi Commentary, Chikitsa sthana, Chapter 24/51, Vol. I., Varanasi: Chaukhamba Sanskrit Sansthan, Reprint edition, 2014, 135p.

50. Nidhi R. Effect of a yoga program on glucose metabolism and blood lipid levels in adolescent girls with polycystic ovary syndrome. Int J Gynaec N Obstetrc. 2012; 118(1):3741.

51. Ansari RM. Kapalabhati pranayama: An answer to modern day polycystic ovarian syndrome and coexisting metabolic syndrome? Int J Yoga 2016; 9: 163-7. 